\title{
Engineering Application of MBR Process to the Treatment of Beer Brewing Wastewater
}

\author{
Haiping Dai \\ State Key Laboratory of Hollow Fiber Membrane Materials and Processes \\ Tianjin Polytechnic University, 300160, China \\ E-mail: daihaiping2004@126.com \\ Xinning Yang \& Tingwei Dong \\ School of Environment and chemical Engineering, Tianjin Polytechnic University \\ Tianjin 300160, China \\ E-mail: lctudtw@163.com \\ Yongwen Ke \& Tao Wang \\ Tianjin MOTIMO Membrane Technology Ltd., Tianjin 300160, China \\ E-mail: keyongwen@163.com
}

\begin{abstract}
According to the characteristics of beer brewing wastewater, Up-flow Anaerobic Sludge Bed and Membrane Bio-Reactor integrated technics (UASB+MBR) was applied. This paper investigated various operating parameters during the process of wastewater treatment in MBRs. The sludge loading and the membrane fouling were analyzed by detecting the sludge concentration and sludge characteristics. The results showed that when $\mathrm{COD}_{\mathrm{Cr}}, \mathrm{NH}_{4}-\mathrm{N}, \mathrm{T}-\mathrm{P}$ and T-N concentrations of the feed water were $500 \sim 1000 \mathrm{mg} / \mathrm{L}, 20 \sim 30 \mathrm{mg} / \mathrm{L}, 0.6 \sim 14 \mathrm{mg} / \mathrm{L}$ and $19.5 \sim 41.1 \mathrm{mg} / \mathrm{L}$, respectively, it got some conclusions in the process.(1)The $\mathrm{COD}_{\mathrm{Cr}}, \mathrm{NH}_{4}-\mathrm{N}, \mathrm{T}-\mathrm{P}$ and T-N of MBR effluent could reduce to $40 \mathrm{mg} / \mathrm{L}, 2.3 \mathrm{mg} / \mathrm{L}, 0.3 \mathrm{mg} / \mathrm{L}, 3 \mathrm{mg} / \mathrm{L}$, respectively. The quality of the effluent water in this system met the reuse of urban recycling water-Water quality standard landscaping water according to GB/T18921-2002; (2)The DO of the aerobic pool should be controlled at the range of 2 4mg/L, which could increase the removing efficiency of the $\mathrm{NH}_{4}-\mathrm{N}$. (3)Appropriate adjustments to the volume of sludge and maintain the sludge concentration of membrane pool at $6 \sim 8 \mathrm{~g} / \mathrm{L}$, which could reduce the velocity of membrane fouling. (4) With $1000 \mathrm{mg} / \mathrm{L}$ of sodium hypochlorite and $2000 \mathrm{mg} / \mathrm{L}$ hydrochloric acid alternate cleaning, the recovery of membrane flux can maintain above $95 \%$.
\end{abstract}

Keywords: Beer brewing wastewater, Membrane Bio-Reactor(MBRs), Operating parameters, Membrane fouling

\section{Introduction}

Beer brewing wastewater mainly comes from the malt workshop, saccharification workshop, fermentation workshop, filling workshop and cooling waste water of productive use. Beer brewing wastewater mainly contains saccharide, alcohols and other organic matter, high concentrations of organic matter. Although non-toxic, they are ease of corruption, when be discharged into the water body, they consume a large amount of dissolved oxygen,and cause serious pollution to the environment. The quality and quantity of brewery wastewater will be changed in different seasons. At the peak flow of beer wastewater, organic matter content is also at its peak. The ratio of $\mathrm{BOD}_{5} / \mathrm{COD}_{\mathrm{Cr}}$ is high in Brewery wastewater, generally reach to 0.5 and above, and it is conducive to biochemical treatment. Comparing biochemical treatment with general physico-chemical method and chemical method, it have three advantages:(1) the treatment technology is mature ; (2) It has high efficiency in $\mathrm{COD}_{\mathrm{Cr}}$ and $\mathrm{BOD}_{5}$ removal and good treatment effect, usually ranging from $80 \%$ to $90 \%$ or more; (3) it is efficient and low cost in investment. Therefore, the biological method has been drawn adequate attention and been widely used in beer wastewater treatment (Kuang, 2006, 62 66).

According to the characteristics of beer brewing wastewater, a brewhouse in Tianjin use MBR treatment method, and its design treatment capacity is $4000 t$ per day. The main evaluation index of influent and effluent in the MBR system includes $\mathrm{PH}$, Turbidity, $\mathrm{COD}_{\mathrm{Cr}}$, Ammonia-N, TN and TP etc. By adjusting the MBR process operating parameters, to optimize the sludge characteristics and then relieve membrane fouling, prolonging membrane 
cleaning cycle, reducing operating costs, making sure that chemical and biological processes and membrane processes achieve the best effects.

\section{Introduction of the project}

\subsection{Design ideas of the brewery wastewater treatment plant}

The process of wastewater treatment was according to the characteristics of wastewater and the effluent requirements. The brewery used UASB process as pretreatment, and $\mathrm{COD}_{\mathrm{Cr}}$ reduced from $2000 \sim 2500 \mathrm{mg} / \mathrm{L}$ to $500 \sim 1000 \mathrm{mg} / \mathrm{L}$, then the UASB effluent entered the MBR system for deep treatment, the water quality of effluent standards for the landscape and recreation area.

2.2 Treatment scale: $4,000 \mathrm{t}$ per day, outflow rate: $208 \mathrm{~m}^{3} / \mathrm{h}$.

\subsection{Treatment process of $M B R$}

2.3.1 The process was reliable, simple operation, stable effluent quality, low operation cost, highly degree of automation. According to the characteristics of influent quality and effluent quality requirements, we used the process flow shown in Fig1.

\subsubsection{Description of the process}

\section{(1) Process feature}

Multi-segment AO+MBR process was used. The process could effectively degrade Ammonia-N and organic matter in beer wastewater, anoxic segment and return activated sludge system could enhance the effects of nitrification. This system could achieve nitrogen removal functions under nitrification and denitrification. Biological phosphorus removal process includes aerobic pool and anaerobic pool. In the anaerobic pool, storing phosphorus germ transformed biodegradable micro-organisms into the body of the carbon source, and consume intracellular storage of poly-phosphate, at the same time release of orthophosphate to the water body. In the aerobic pool, storing phosphorus germ consumed carbon stored in cell, and transformed solubility of inorganic phosphorus into the intracellular storage of poly-phosphate, so as to achieve phosphorus removal function(Zeng, Yiming, 2007). The high interceptor capability of membrane made sludge concentration achieving higher levels in MBR, increasing the effect of removal of ammonia-N and organic matter and improve effluent quality.

(2) System structure

The system included biochemical system, membrane filtration system, membrane cleaning system, control system, electrical and mechanical systems. Biochemical systems included anoxic stage and aerobic stage, the returned sludge and mud discharging systems, water quality parameter testing systems etc. Adjusting the aeration volume and drug flow rate of pre-process by on-line detection of dissolved oxygen, $\mathrm{pH}$ and other parameters.

(3) Membrane module

Membrane modules were external pressure submerged hollow fiber membrane made by Tianjin MOTIMO Membrane Technology Co.,Ltd. Hollow fiber membrane was made of polyvinylidene fluoride (PVDF), and it was resistant to sodium hypochlorite, chlorine dioxide and other oxidants, at the same time it had long life performance. We can use common fungicides, such as $\mathrm{NaClO}$ and hydrochloric acid, as a bactericidal and membrane cleaning agent. Membrane working pressure was low, and at ranging of $10 \sim 50 \mathrm{kPa}$, so its energy consumption was lower than other technologies. The whole system of water production adopted automatic control, $8 \mathrm{~min}$ run and $2 \mathrm{~min}$ stop.

\subsubsection{Raw water quality}

(1) MBR influent water source: UASB system effluent.

(2) After pre-treatment of UASB process, quality of wastewater include $\mathrm{COD}_{\mathrm{Cr}}$ concentration of $500 \sim 1000 \mathrm{mg} /$ L, Ammonia-N concentration of $20 \sim 30 \mathrm{mg} / \mathrm{L}$, et al.

\subsubsection{Outflow quality requirements}

The outflow quality meet the standard of landscaping water reuse, Main water indicators: $\mathrm{COD}_{\mathrm{Cr}} \leq 40 \mathrm{mg} / \mathrm{L}$, $\mathrm{BOD}_{5} \leq 10 \mathrm{mg} / \mathrm{L}, \mathrm{SS} \leq 10 \mathrm{mg} / \mathrm{L}, \mathrm{NH}_{4}-\mathrm{N} \leq 5 \mathrm{mg} / \mathrm{L}, \mathrm{TP} \leq 0.5 \mathrm{mg} / \mathrm{L}, \mathrm{TKN} \leq 10 \mathrm{mg} / \mathrm{L}$.

\section{Effect of the operation}

\subsection{Analysis of influent and effluent quality}

3.1.1 Effect of the $\mathrm{COD}_{\mathrm{Cr}}$ removal by MBR

As shown in figure 2, the $\mathrm{COD}_{\mathrm{Cr}}$ of feed water at the maximum value of $1626 \mathrm{mg} / \mathrm{L}$ and the minimum value of 
$641.9 \mathrm{mg} / \mathrm{L}$, while it is at mean value of $1018.95 \mathrm{mg} / \mathrm{L}$; the $\mathrm{COD}_{\mathrm{Cr}}$ of permeate water an average value of $40.20 \mathrm{mg} / \mathrm{L}$, its minimum value reach to $4 \mathrm{mg} / \mathrm{L}$, and the average removal rate is up to $96.05 \%$. $\mathrm{COD}_{\mathrm{Cr}}$ of the test water production is higher than $50 \mathrm{mg} / \mathrm{L}$ during the $13 \sim 17$ times because of beer production equipment maintenance, no waste water and MBR system stopped running for a week. At the start-up phase, the sludge concentration is low and microbial performance unadapted to wastewater quality, so treatment efficiency declined. Running through a week to restore, in the case of fluctuations in feed water quality, permeate water quality is stable and MBR shows a stronger tolerance to fluctuation loading.

\subsubsection{Effect of Ammonia-N removal}

As shown in figure 3, the Ammonia- $\mathrm{N}$ concentration of feed water was averaged $23.69 \mathrm{mg} / \mathrm{L}$, and the Ammonia-N concentration of permeate water was averaged $1.903 \mathrm{mg} / \mathrm{L}$, removal efficiency reach to $91.97 \%$. In the two-month monitoring period, permeate water was tested 25 times, and the ammonia-N concentration exceeded $5 \mathrm{mg} / \mathrm{L}$ for only two times. The analysis concluded that Ammonia-N concentration high of initial testing was due to instability of the feed water, and resulted in large fluctuations of dissolved oxygen concentration in aerobic pool, affecting the nitration reaction, thus leading to instability in the value of the Ammonia-N of permeate water. When the feed water was continuous and stable, aerobic pool dissolved oxygen concentration was controlled at the range of $2 \sim 4 \mathrm{mg} / \mathrm{L}$ by adjusting the air volume. After half month running the Ammonia- $\mathrm{N}$ concentration reduced to $1 \mathrm{mg} / \mathrm{L}$ and remained stable.

\section{$3.1 .3 \mathrm{pH}$}

The $\mathrm{pH}$ value of feed water was stable, with an average 7.69, which was suitable for microbial growth. The $\mathrm{pH}$ of the permeate water was averaged 8.35 , somewhat higher than the feed water, which is due to micro-organisms consuming of organic acids in the process of decomposition of organic matter.

\subsubsection{Effect of Nitrogen and Phosphorus Removal}

The mechanism of T-P removal: The T-P concentration was tested five times, and the T-P concentration of feed water was changed from $0.63 \mathrm{mg} / \mathrm{L}$ to $14.76 \mathrm{mg} / \mathrm{L}$, but the T-P concentration of permeate water was below $0.3 \mathrm{mg} / \mathrm{L}$ stably. The T-N concentration of feed water was at the range of $19.5 \sim 41.1 \mathrm{mg} / \mathrm{L}$, the permeate water T-N was at the range of $0.6 \sim 2.3 \mathrm{mg} / \mathrm{L}$. The test result indicated that it was ideal effect of nitrogen and phosphorus removal, and this craft was reasonable.

\subsubsection{Turbidity removal}

Turbidity was an very important indicator of the senses in wastewater reuse. After two months testing, the turbidity of permeate water was $0.24 \sim 0.52 \mathrm{NTU}$, the permeate water was clear and could meet the requirements of discharge standard.

\section{2 sludge loading of biochemical pool}

Sludge concentration of the system was $6000 \sim 10000 \mathrm{mg} / \mathrm{L}$. Sludge loading as an important biochemical parameters of the system, which could be used to estimate the biochemical process operating conditions of the MBR and be adjusted operating parameters, by calculating the sludge loading.

As shown in table 1 , it showed that the sludge CODCr loading averaged $0.286 \mathrm{KgCOD} / \mathrm{KgMLSS} \cdot \mathrm{d}$, sludge load fluctuated from 0.177 to 0.429 . Owing to the fluctuation of feed water quality, the impact load on the sludge was large, which led to bad settleability of activated sludge.

\subsection{The regulation of operating parameters and control of membrane fouling}

\subsubsection{Dissolved oxygen in aerobic pool}

At the initial operation of the project, dissolved oxygen concentration fluctuated at the range of $0.02 \sim 6 \mathrm{mg} / \mathrm{L}$, and it was very unstable and presented parabolic-type cycle trend. This fluctuation was caused by the unbalanced quantity between feed water and permeate water: when producing water, the biochemical pool was at a low level in a very short time, and then stopped producing water, in this situation a continuous influent caused dissolved oxygen concentration of aerobic pool decline to $0.5 \mathrm{mg} / \mathrm{L}$ below sharply; when the biochemical pool at a high water level, the wastewater of system stopped flowing into MBR. Due to excessive aeration, dissolved oxygen rose to more than $5 \mathrm{mg} / \mathrm{L}$ sharply, which affected not only the normal microbial decomposition of organic material but also wasting of electrical energy.

There were literatures indicating that: (1) when the dissolved oxygen concentration was higher than $4 \mathrm{mg} / \mathrm{L}$, microbial decomposition of carbohydrates increased, these hydrophobic substances would be adsorbed on the wall of the membrane pore, and this covering layer on membrane surface was difficult to wipe off by shearing 
force. In addition, the adsorption increased membrane fouling and made cake layer thicker, therefore the frequency of membrane cleaning increased (Zeng, 2007); (2) when dissolved oxygen concentration was lower than $0.5 \mathrm{mg} / \mathrm{L}$, the aerobic bacteria was on anaerobic condition in aerobic pool, and this anaerobic condition would facilitate the growth of filamentous bacteria and cause sludge bulking, which also aggravated membrane fouling (Gao, 2001, P12 15). By means of summarizing the operational experience, adjusting the height of liquid indicator, frequently short-term inflow, reducing the fluctuations of dissolved oxygen concentration, the dissolved oxygen concentration could be kept on the rang of $2 \sim 3 \mathrm{mg} / \mathrm{L}$. In this condition, micro-organisms could keep the biochemical effects and sludge properties ideal.

\subsubsection{Aeration intensity of the membrane tank}

Adopting the hole with coarse aeration tube at the bottom of membrane modules could maintain membrane fiber in mixture turbulent fluctuation in wastewater, slow down the sludge deposited on the membrane surface, controll membrane fouling and prolong membrane useful time (Zhang, 2004, P11 15). Large aeration increased energy consumption, though small aeration increased membrane fouling. According to experiments with membrane filtration resistance and analysis of sludge characteristics, we concluded that the best ratio of membrane aeration volume and permeate water volume was 12:1 15:1.

\subsubsection{Sludge concentration of aerobic tank and membrane tank}

As shown in figure 4, the MLSS variation tendency of membrane tank and anoxic tank MLSS was shown in Figure 4. At the beginning the sludge concentration of membrane tank was $11690 \mathrm{mg} / \mathrm{L}$ and the anoxic tank was $9660 \mathrm{mg} / \mathrm{L}$. It indicated that sludge concentration was higher, sludge settling was not well, and also the floc size was very small, so it accelerated membrane fouling, increased membrane filtration pressure and flux reduce. A certain increase of sludge concentration could improve the efficiency of the reactor, but with the increase of sludge concentration, leading to the mixture viscosity became greater and membrane filtration resistance increased, and the membrane flux was affected (Liu, 2001, P20 24). The sludge concentration of $6 \sim 8 \mathrm{~g} / \mathrm{L}$ was better.

\subsubsection{Settling Velocity SV30}

During the experiment, SV30 was tested once everyday, and the SV30 of membrane tank was at the range of $93 \% \sim 98 \%$, SVI at $100 \sim 160 \mathrm{ml} / \mathrm{g}$. As the sludge concentration of biochemical tank was high and settling was very different from the conventional activated sludge process, the sludge settling characteristics have relationship on the extent of membrane fouling. Sludge was divided into granular sludge and floc sludge by aggregation morphology, and the settling performance of granular sludge was better than floc sludge, because it was easier to reverse back into the mixture from membrane surface, and it was difficult to form a cake layer. The specific surface of floc sludge was larger than the granular sludge, which meant that it was more likely to extracellular polymeric substances adsorbed on the membrane surface, comparing to granular sludge more difficult to lead to fouling of adsorption (Zheng, 2001, P41 44). Improving the sludge settling was also a way to reduce the membrane fouling. Experiment showed that the sludge concentration was controlled at the range of $6 \sim 8 \mathrm{~g} / \mathrm{L}$, sludge SV30 below $80 \%$, which may slow down the speed of membrane fouling.

\section{Conclusion}

1) Using MBR method treating brewery wastewater achieved good effect of CODCr removal, NH4-N removal and T-P removal, and the index of permeate water were: $\mathrm{CODCr}<50 \mathrm{mg} / \mathrm{L}, \mathrm{NH} 4-\mathrm{N}<5 \mathrm{mg} / \mathrm{L}, \mathrm{T}-\mathrm{P}<0.3 \mathrm{mg} / \mathrm{L}$, $\mathrm{TN}<5 \mathrm{mg} / \mathrm{L}$. The outflow quality was better than the reuse water standard in GB/T18921-2002.

2) The volume of feed water and permeate water was as evenly as possible, the dissolved oxygen of aerobic tank controlled at $2 \sim 3 \mathrm{mg} / \mathrm{L}$, the sludge concentration of membrane tank was at $6 \sim 8 \mathrm{~g} / \mathrm{L}$, the sludge settling ratio and biochemical effect were good.

3) The ratio of membrane aeration volume and the water production controlled at the range of 12:1 15:1 that could alleviate the membrane fouling effectively.

\section{Acknowledgments}

The research was supported and by Nature Science Fund of China (50808130)

\section{References}

Gao chun-di, Wang shu-ying \& Yin bo. (2001). Influence of DO on Organic Matter Degradation Rate and Sludge Settling Property. China Water \& Wastewater, 17(5):12 15.

Kuang Wu et al. (2006). Application of Upflow Anaerobic Sludge Blanket Process to a Brewery Wastewater 
Treatment[J].China water \& wastewater, 22(16): 62 66.

Liu rui, Huang xia, et al. (2001). A Comparison between a Submerged Membrane Bioreactor and a Conventional Activated Sludge Process[J]. Chinese Journal of Environmental Science, 22(3):20 24.

Zeng yi-ming. (2007). Membrane bio-reactor technology. Bei jing: National Defence Industry Press (chapter 4).

Zhang chuan-yi, Wang yong, et al. (2004). Experimental study on economical aeration intensity in a submerged membrane bioreactor[J]. Membrane science and technology. 24(5): 11 15.

Zheng xiang, Fan yao-bo. (2001). Optimization of the Operation Parameters on MBR and Membrane Fouling Control[J]. Water \& Wastewater engineering, 27(4): 41 44.

Table 1. Sludge concentration and Sludge loading

\begin{tabular}{|c|c|c|c|c|c|c|c|c|c|}
\hline 1 & 1 & 2 & 3 & 4 & 5 & 6 & 7 & 8 & 9 \\
\hline MLSS(mg/L) & 9660 & 6120 & 6922 & 6262 & 7800 & 6726 & 8016 & 7802 & 7774 \\
\hline $\begin{array}{c}\text { Sludge loading } \\
\text { (Kg COD/Kg } \\
\text { MLSS·d) }\end{array}$ & $\begin{array}{c}0.22 \\
5\end{array}$ & 0.302 & 0.363 & 0.224 & 0.354 & 0.217 & 0.429 & 0.283 & 0.177 \\
\hline
\end{tabular}

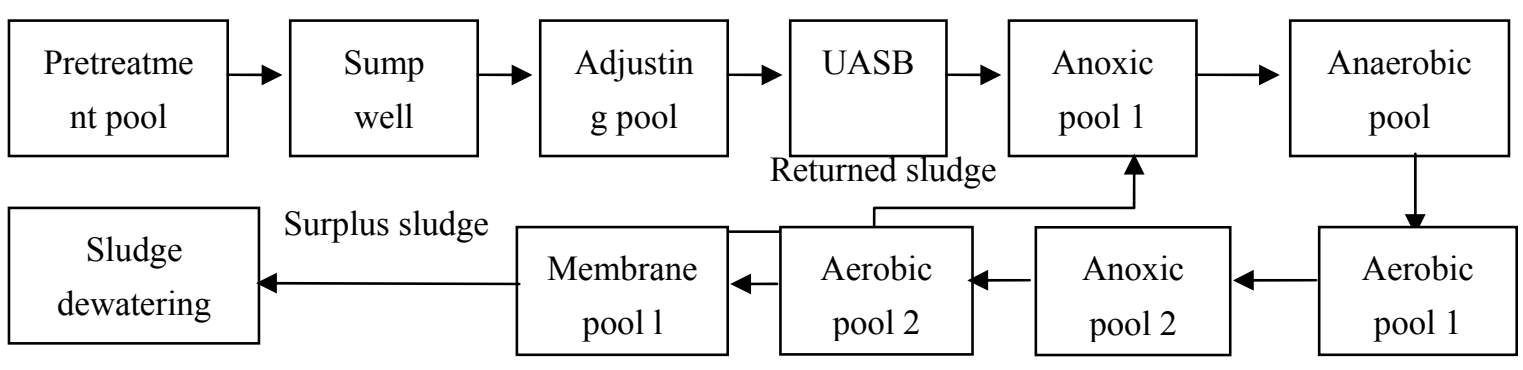

Figure 1. Schematic diagram of the project 


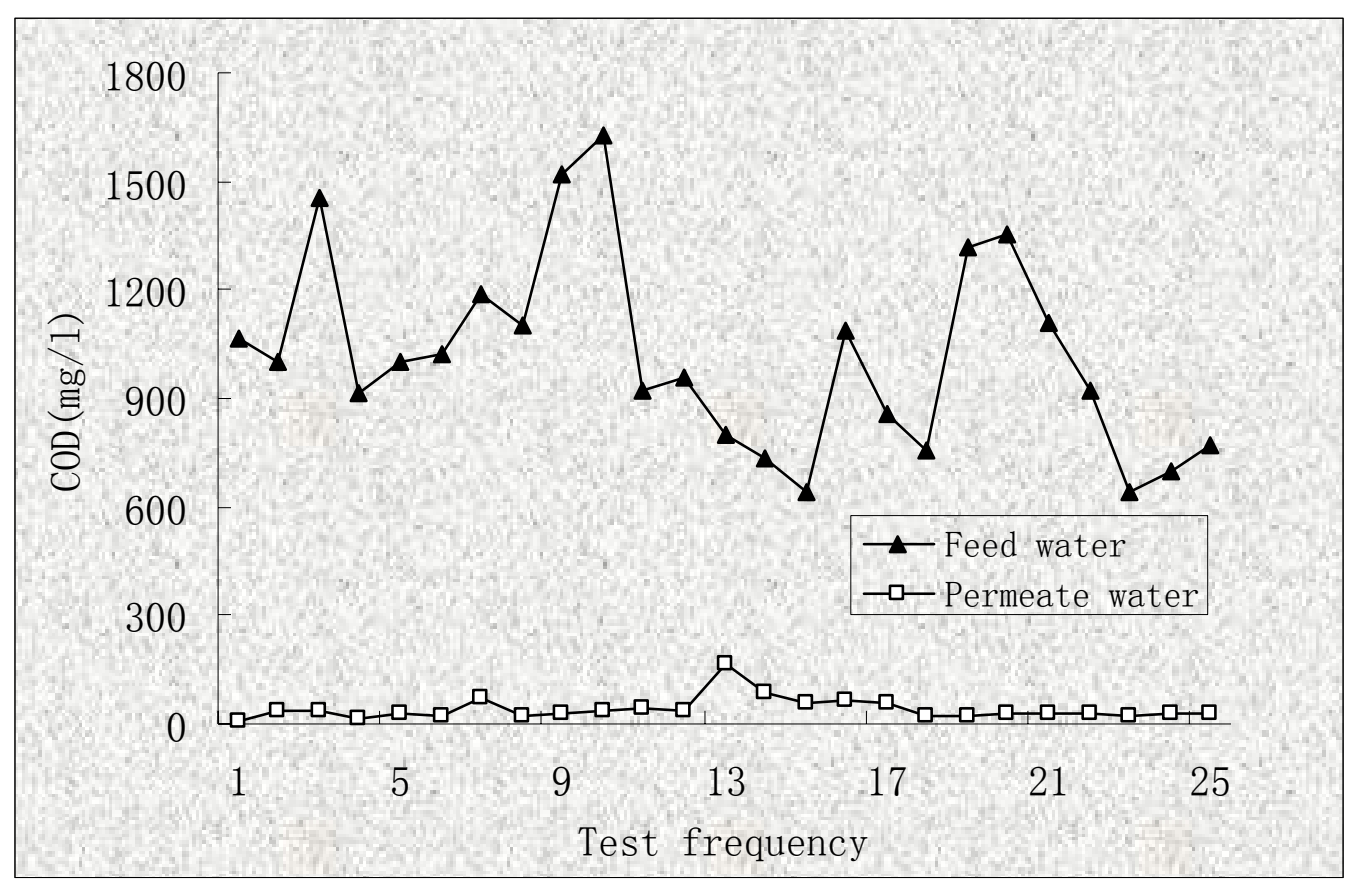

Figure 2. Effect of the $\mathrm{COD}_{\mathrm{Cr}}$ removal by MBR

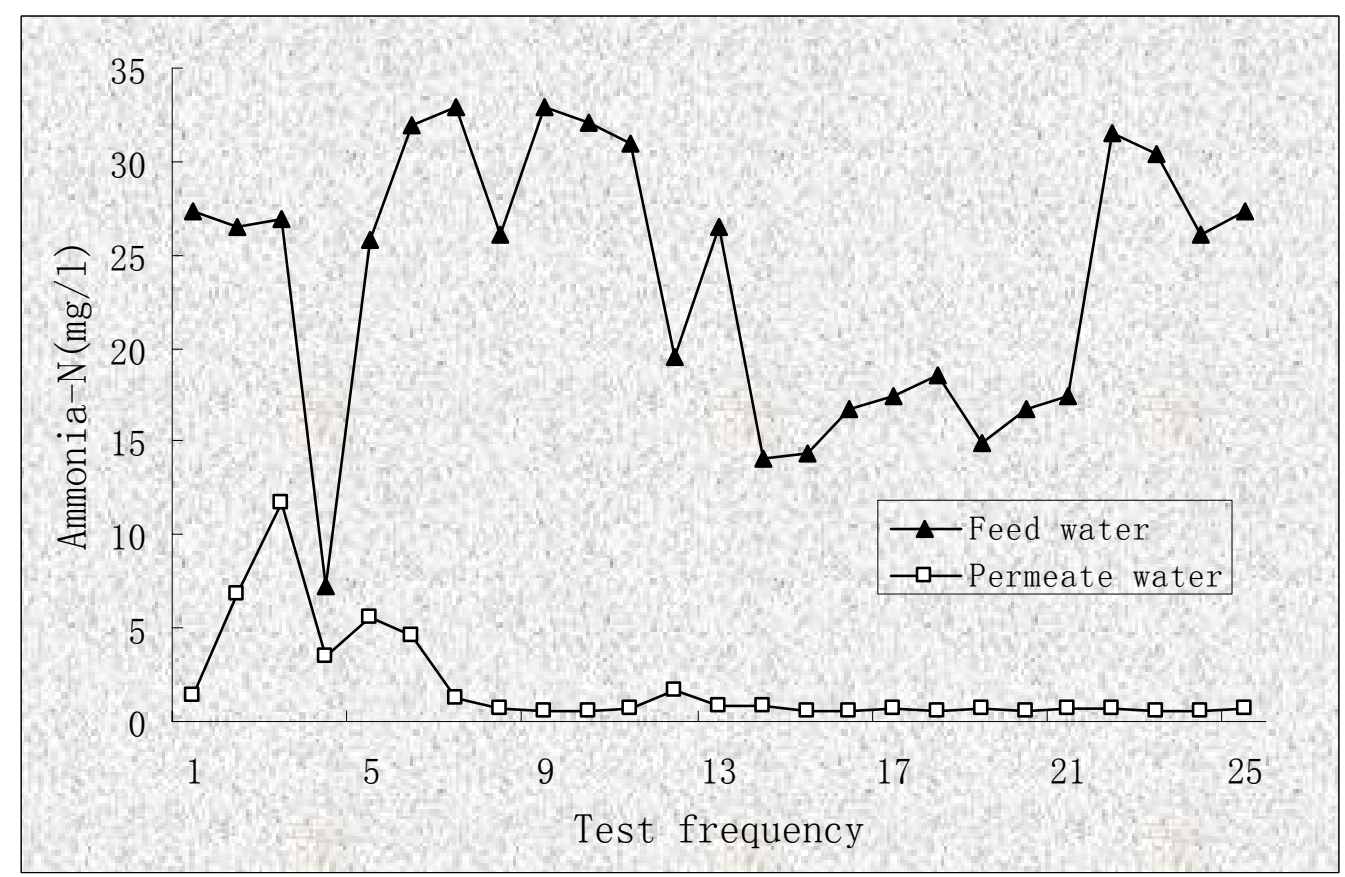

Figure 3. Ammonia-N of MBR system influent and effluent 


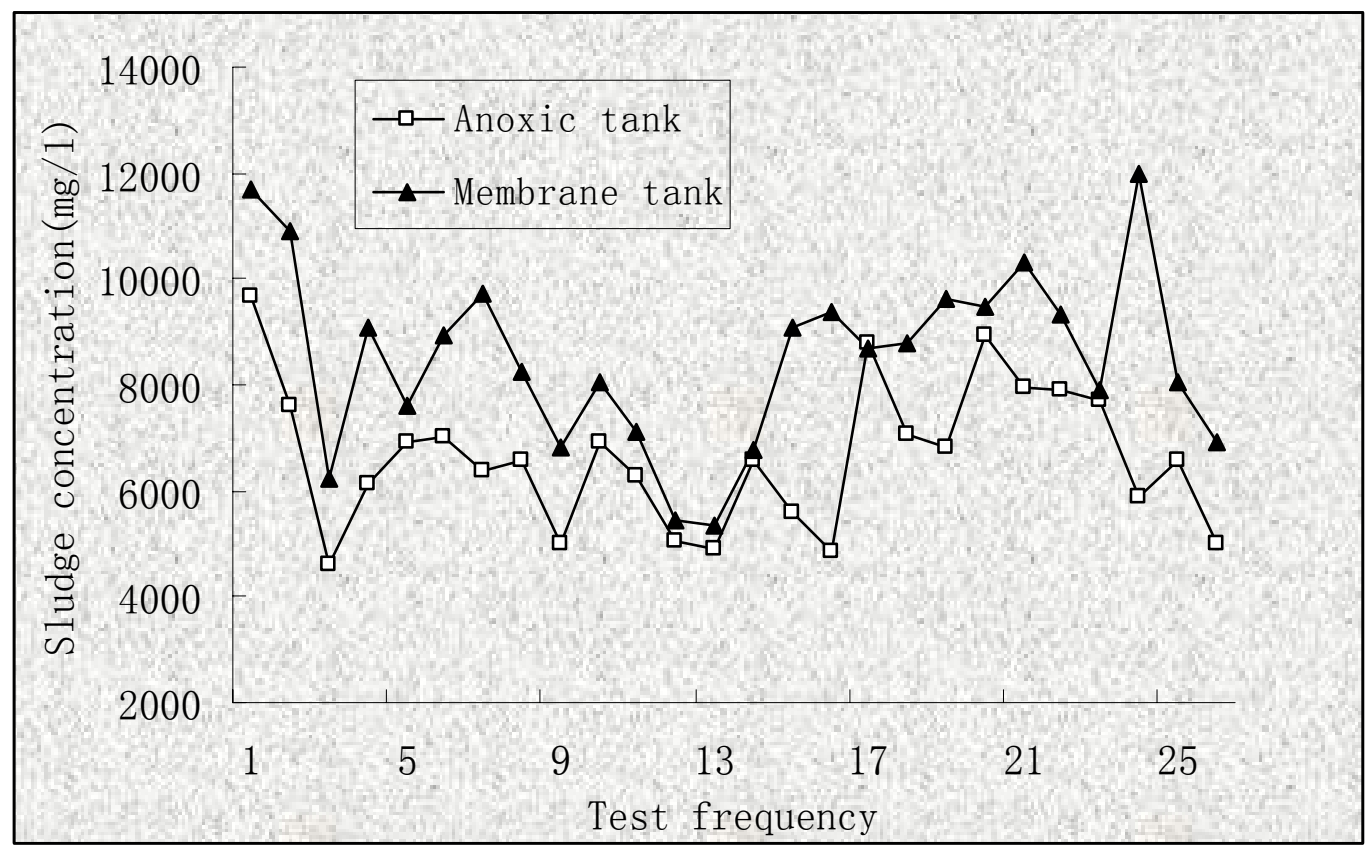

Figure 4. The sludge concentration in Anoxic tank and Membrane tank 